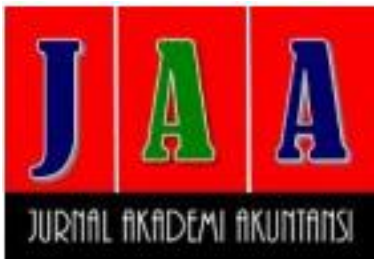

Diterima : 27 November 2019

Direview : 28 November 2019

Direvisi : 06 Desember 2019

Diterima : 06 Desember 2019

Artikel ini tersedia di

website:

http://ejournal.umm.ac.id/i

ndex.php/jaa

\section{FAKTOR-FAKTOR YANG MEMPENGARUHI KEPATUHAN WAJIB PAJAK DI KKP PRATAMA PAMEKASAN}

\author{
Anniza Hidayana Famami*, Norsain \\ Program Studi Akuntansi Fakultas Ekonomi dan Bisnis \\ Universitas Wiraraja \\ J1. Raya Sumenep-Pamekasan KM. 05 Patean, Panitian Utara, Patean, Batuan, \\ Kabupaten Sumenep, Jawa Timur \\ *Corresponding author: Anizhf17@gmail.com
}

\begin{abstract}
Indonesia's income in the tax sector is the biggest contributor to the state budget. State revenue from the tax sector still leaves problems because Indonesia's tax ratio is relatively low. This is an indication that there is a lack of awareness of taxes in the community. The research objective was to analyze the factors that influence taxpayer compliance at KPP Pratama Pamekasan.

This type of research is quantitative research. Place of research in KPP Pratama Pamekasan for one month starting May-June 2019. The study population was the number of taxpayers registered at Pamekasan Primary Tax Office as much as 11,703. The sample is 100 taxpayers. Multiple linear regression analysis test.

The results of the t test on the knowledge variable obtained the value of $p$ value $(0,014)<$ 0,05 and perception $(0,026)<0,05$ which means that there is an influence of knowledge and perceptions of tax compliance at Pamekasan Primary Tax Office, In the tax amnesty variable, $p$ value $(0,516)>0,05$, sanction $(0,620)>0,05$, examination $(0,815)>0,05$, awareness $(0,154)>0,05$, and tax service $(0,147)>0,05$ were observed, meaningful tax amnesty, sanctions, checks, awareness, and service have no effect on tax compliance at KPP Pratama Pamekasan, The results of the $F$ test obtained a value $(0,005)<0,05$ which means tax amnesty, sanctions, examination, awareness, knowledge, perception, and service simultaneously and significantly affected tax compliance at KPP Pratama Pamekasan.
\end{abstract}

Keywords: tax amnesty, sanctions, examination, and compliance

\section{PENDAHULUAN}

Sumber penerimaan negara berasal dari berbagai sektor, baik sektor luar maupun dalam negeri (Denziana \& Susanto, 2015). Ada tiga sumber penerimaan negara yang digunakan untuk membiayai belanja negara, yaitu pajak, penerimaan negara selain pajak, dan hibah.Sumber terbesar pendapatan negara berasal dari pajak. Dalam upaya menuju kemandirian perekonomian, pemerintah terus 
mengeluarkan kebijakan untuk mengoptimal-kan penerimaan internal, yaitu penerimaan sektor pajak. Beberapa tahun terakhir, pajak menjadi sumber penerimaan negara dengan prosentase terbesar dalam Anggaran Pendapatan dan Belanja Negara (APBN).

Pajak menjadi pilihan utama dalam upaya peningkatan penerimaan negara karena memiliki potensi yang tidak terbatas. Pada tahun 2015 pendapatan Indonesia di sektor pajak menjadi penyumbang terbesar APBN. Penerimaan dari sektor pajak dapat terus ditingkatkan dan menjadi sumber penerimaan yang tidak akan pernah habis. Selain itu objek pajak dapat diperluas seiring perkembangan perekonomian (Suyono dan Nanang, A., 2016). Penerimaan negara dari sektor pajak masih meninggalkan masalah.

Tax ratio Indonesia masih rendah karena berada pada kisaran $10-11 \%$ selama periode 2012-2017 dan cenderung menurun pada tiga tahun terakhir.Jika dibandingkan dengan rata-rata dunia, rasio pajakIndonesia relatif rendah. World bank menyebutkan bahwa tax ratio Indonesia jika dibandingkan dengan 5 negara ASEAN selama tahun 2011-2015, berada pada posisi paling rendah dikisaran 11,12 hingga $10,75 \%$. Hal ini merupakan indikasi bahwa adanya kesadaran akan pajak yang masih kurang di masyarakat (Listyowati dkk., 2018).

Rendahnya tingkat kepatuhan membayar pajak menjadi salah satu penyebab belum optimalnya penerimaan pajak di Indonesia. Kepatuhan wajib pajak dalam membayar pajak seharusnya merupakan posisi strategis dalam upaya peningkatan penerimaan negara dari sektor pajak. Oladipupo dan Obazee (2016) menyatakan bahwa di banyak negara berkembang, administrasi perpajakan biasanya lemah dan ditandai dengan penggelapan, korupsi, dan paksaan. Menurut Oladipupo dan Obazee (2016), faktor-faktor yang memengaruhi rendahnya tingkat kepatuhan pajak di negara-negara berkembang antara lain sikap, hukuman/ sanksi, pendapatan, pengetahuan, jenis kelamin dan usia wajib pajak, korupsi, tingkat pajak marjinal yang tinggi, kurangnya ketersediaan sistem informasi dan akuntansi, sektor informal yang besar, sistem peraturan yang lemah, ambiguitas dalam undang-undang perpajakan, adanya budaya yang tidak patuh, dan ketidakefektifan administrasi perpajakan.

Menurut James dan Alley (2004) dalam Listyowati dkk., (2018) menyatakan bahwa tidak mudah membujuk semua wajib pajak untuk mematuhi semua persyaratan sistem perpajakan. Kepatuhan pajak cenderung menjadi aspek yang lebih signifikan dari kebijakan pajak. Hal ini disebabkan sebagian besar masalah lama yang masih tetap ada dan adanya pertimbangan baru yang berkembang seperti self assessment, kemunculan ekonomi global, dan perdagangan elektronik. Kepatuhan wajib pajak dipengaruhi oleh berbagai faktor, di antaranya program atau kebijakan pemerintah, pengetahuan tentang peraturan perpajakan, dan pelayanan pajak. Program pemerintah dalam upaya meningkatkan kepatuhan wajib pajak antara lain kebijakan sunset policy, tax amnesty, sanksi perpajakan, dsb.

Penelitian sebelumnya menunjukkan hasil yang berbeda-beda, sehingga memotivasi peneliti untuk melakukan penelitian faktor-faktor yang memengaruhi 
kepatuhan wajib pajak. Berdasarkan latarbelakang tersebut, penelitian ini dimaksudkan untuk: mengetahui bahwa tax amnesty, sanksi pajak, pemeriksaan (audit probabilities), kesadaran status demografi (pendidikan), pengetahuan tentang pajak, persepsi atas efektivitas sistem perpajakan, dan pelayanan pajak terhadap kepatuhan wajib pajak.

\section{METODE PENELITIAN}

Jenis penelitian ini adalah penelitian kuantitatif didasarkan pada asumsi bahwa kepatuhan wajib pajak yang menjadi sasaran penelitian berdimensi tunggal, fragmental, dan cenderung bersifat tetap sehingga dapat diprediksi. Tempat penelitian di KPP Pratama Pamekasan. Waktu penelitian selama satu bulan mulai bulan Mei-Juni 2019. Populasi penelitian ini adalah wajib pajak terdaftar di KPP Pratama Pamekasan yang berjumlah 11.703 (pemungut Kabupaten Pamekasan dan Sumenep) dengan wajib pajak terdaftar di Kabupaten Sumenep sebanyak 7.217 orang $(61,67 \%)$ dan wajib pajak terdaftar di Kabupaten Pamekasan sebanyak 4.485 orang $(38,33 \%)$.

Besar sampel penelitian berjumlah 100 orang dengan ketentuan: 1) sampel wajib pajak terdaftar Kabupaten Sumenep 61,67\% x $100=.61,67=62$ orang; dan 2) sampel wajib pajak terdaftar Kabupaten Pamekasan 38,33\% x $100=38,33=38$ orang. Pengumpulan data primer dilakukan dengan metode survei menggunakan kuisioner. Variabel independen adalah tax amnesty, sanksi pajak, pemeriksaan (audit probabilities), kesadaran, pengetahuan tentang pajak, persepsi atas efektivitas sistem perpajakan, dan pelayanan pajak. Variabel dependen adalah kepatuhan wajib pajak. Uji instrumen menggunakan uji Pearson correlation dan Cronbach Alpha. Uji prasarat analisis menggunakan uji normalitas Kolgomorov-Smirnow dan linearitas scatterplot, uji Multikolinearitas, uji Autokorelasi run test, uji Heteroskedastisitas scatterplot. Uji analisis korelasi menggunakan uji Regresi Berganda dengan uji beda t-test dan Simultan (Uji F)

\section{HASIL PENELITIAN}

\section{Karakteristik Repsonden}

1. Jenis Kelamin Responden

\begin{tabular}{ccc}
\hline Jenis kelamin & $\mathrm{F}$ & $\%$ \\
\hline Laki-Laki & 67 & 67,0 \\
Perempuan & 33 & 33,0 \\
\hline Jumlah & 100 & 100,0 \\
\hline
\end{tabular}

Sumber : Data Primer, 2019

Sebagian besar responden berdasarkan jenis kelamin adalah laki-laki, yaitu sebanyak 67 orang $(67,0 \%)$. 
2. Umur Responden

\begin{tabular}{lcc}
\hline \multicolumn{1}{c}{ Umur } & Frekuens & $\begin{array}{c}\text { Persentase } \\
(\%)\end{array}$ \\
\hline Remaja (akhir dan ki & 1 & 10,0 \\
Dewasa (awal dan ak & 4 & 48,0 \\
Lansia & 4 & 42,0 \\
(awal, akhir, dan mar & 100 \\
\hline \multicolumn{2}{c}{ Jumlah } \\
\hline \multicolumn{2}{c}{ Sumber : Data Primer, 2019 }
\end{tabular}

Hampir setengah responden berdasarkan umur adalah dewasa (awal/ 26-35 tahun dan akhir/ 36-45 tahun), yaitu sebanyak 48 orang (48,0\%).

3. Pendidikan Responden

\begin{tabular}{ccc}
\hline Pendidikan & $\begin{array}{c}\text { Frekuensi } \\
(\mathrm{f})\end{array}$ & $\begin{array}{c}\text { Persentase } \\
(\%)\end{array}$ \\
\hline $\begin{array}{c}\text { Dasar (SD dan } \\
\text { SMP) } \\
\text { Lanjutan (SMA) }\end{array}$ & 10 & 10,0 \\
$\begin{array}{c}\text { Perguruan tinggi } \\
\text { (D2, D3, S1, dan } \\
\text { S2) }\end{array}$ & 49 & 49,0 \\
\hline Jumlah & 41,0 \\
\hline \multicolumn{2}{c}{ Sumber : Data Primer, 2019 }
\end{tabular}

Hampir setengah pendidikan responden adalah pendidikan lanjutan (SMA), yaitu sebanyak 49 orang (49,0\%).

4. Pekerjaan Responden

\begin{tabular}{ccc}
\hline Pekerjaan & $\mathrm{f}$ & $\%$ \\
\hline PNS, TNI, POLRI & 33 & 33,0 \\
Karyawan swasta & 15 & 15,0 \\
Wiraswasta & 52 & 52,0 \\
\hline Jumlah & 100 & 100 \\
\hline
\end{tabular}

Sumber : Data Primer, 2019

Sebagian besar responden berdasarkan pekerjaan adalah wiraswasta, yaitu sebanyak 52 orang $(52,0 \%)$.

5. Status Perpajakan Responden

\begin{tabular}{ccc}
\hline Status & $\mathrm{f}$ & $\%$ \\
\hline Perorangan & 87 & 87,0 \\
Badan & 13 & 13,0 \\
\hline Jumlah & 100 & 100,0 \\
\hline
\end{tabular}

Sumber : Data Primer, 2019

Sebagian besar responden berdasarkan status perpajakan adalah perorangan, yaitu sebanyak 87 orang $(87,0 \%)$. 
6. Lokasi Responden

\begin{tabular}{ccc}
\hline Lokasi & $\mathrm{f}$ & $\%$ \\
\hline Sumenep & 62 & 62,0 \\
Pamekasan & 38 & 38,0 \\
\hline Jumlah & 100 & 100,0 \\
\hline
\end{tabular}

Sumber : Data Primer, 2019

Sebagian besar responden berdasarkan lokasi adalah sumenep, yaitu sebanyak 62 orang $(62,0 \%)$.

\section{Data Khusus}

1. Uji Instrumen

a. Uji Validitas

\begin{tabular}{|c|c|c|c|c|c|c|c|c|c|c|}
\hline \multirow{2}{*}{ riabel $^{\mathrm{Va}}$} & \multicolumn{10}{|c|}{ Corrected Item-Total Correlation (setiapitem } \\
\hline & 1 & 2 & 3 & 4 & 5 & 6 & 7 & 8 & 9 & 10 \\
\hline $\begin{array}{r}\mathrm{Ta} \\
\text { x Amnesty } \\
\mathrm{Sa}\end{array}$ & 374 & 353 & 639 & 395 & 547 & & & & & \\
\hline nksi & 362 & 536 & 590 & 442 & 502 & 536 & & & & \\
\hline $\begin{array}{r}\text { merik-saan } \\
\text { Ke }\end{array}$ & 389 & 388 & 422 & 389 & & & & & & \\
\hline $\begin{array}{l}\text { sadaran } \\
\qquad \mathrm{Pe}\end{array}$ & 244 & 349 & 516 & 720 & 622 & & & & & \\
\hline $\begin{array}{r}\text { ngeta-huan } \\
\mathrm{Pe}\end{array}$ & 784 & 716 & 596 & 409 & 420 & 359 & 306 & & & \\
\hline $\begin{array}{l}\text { rsespsi } \\
\\
\\
\end{array}$ & 479 & 746 & 373 & 765 & 574 & 428 & 433 & 708 & 672 & 726 \\
\hline $\begin{array}{l}\text { layanan } \\
\text { Ke }\end{array}$ & 349 & 659 & 361 & 544 & 497 & & & & & \\
\hline patuhan & 626 & 481 & 655 & 309 & 655 & 618 & & & & \\
\hline
\end{tabular}

Hasil uji validitas untuk item kuisioner pada masing-masing variabel diperoleh nilai corrected Item-Total Correlation $>0,100$ yang bermakna setiap item kuisioner pada masing-masing variable adalah valid.

b. Uji Reliabilitas

\begin{tabular}{ccc}
\hline \multicolumn{1}{c}{ Variabel } & $\begin{array}{c}\text { Cronbach's } \\
\text { Alpha }\end{array}$ & $\begin{array}{r}\text { N } \\
\text { of Items }\end{array}$ \\
\hline $\begin{array}{c}\text { Tax } \\
\text { Amnesty. }\end{array}$ &, 686 & 5 \\
Sanksi &, 733 & 6 \\
Pemeriksaan &, 606 & 4 \\
Kesadaran &, 707 & 5 \\
Pengetahuan &, 780 & 7 \\
Persespsi &, 858 & 10 \\
Pelayanan &, 684 & 5 \\
Kepatuhan &, 781 & 6 \\
\hline Sumber : Data Primer, 2019 &
\end{tabular}

Hasil uji reliabilitas untuk kuisioner pada masing-masing variabel diperoleh nilai Cronbach's Alpha > 0,60 yang bermakna reliabel atau memiliki konsistensi jika kusioner digunakan pada pengukuran berulang. 


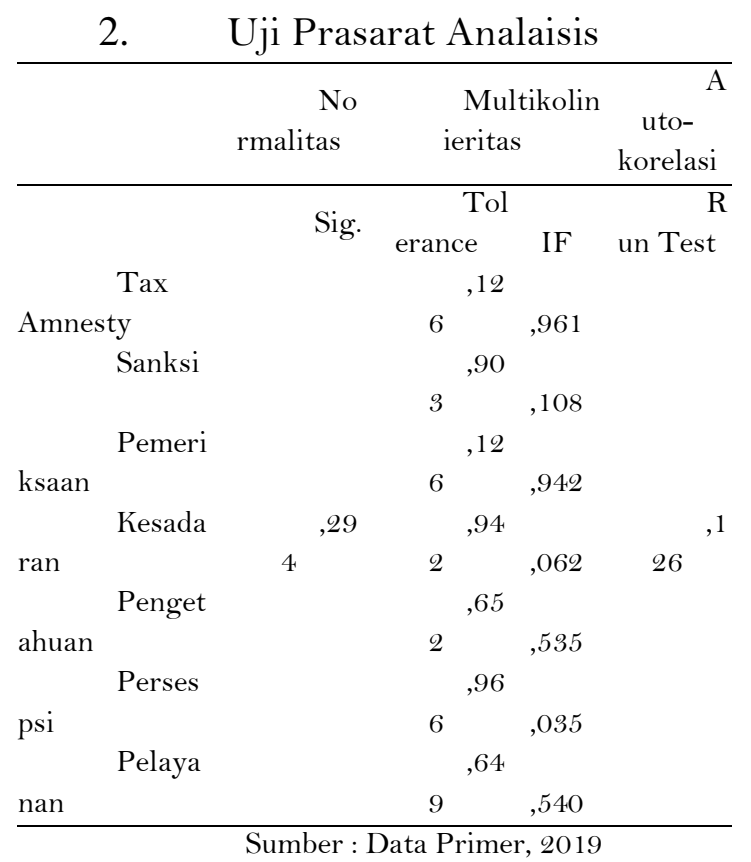

\section{a.Uji Normalitas}

Hasil uji normalitas Kolmogorov-Smirnov Testdiperoleh nilai a $(0,294)>0,005$ yang bermakna nilai residual berdistribusi normal.

b. Uji Multikolinieritas

Hasil uji multikoleniaritas diperoleh nilai tolerance $>0,10$ dan VIF $<10$ yang bermakna tidak terjadi hubungan interkorelasi atau korelasi yang kuat antar variabel independen.

c.Uji Autokorelasi

Hasil uji autokorelasi Run Teestdiperoleh nilai $a=0,126>0,05$ yang bermakna tidak terdapat gejala autokorelasi.

d. Uji Heteroskedastisitas

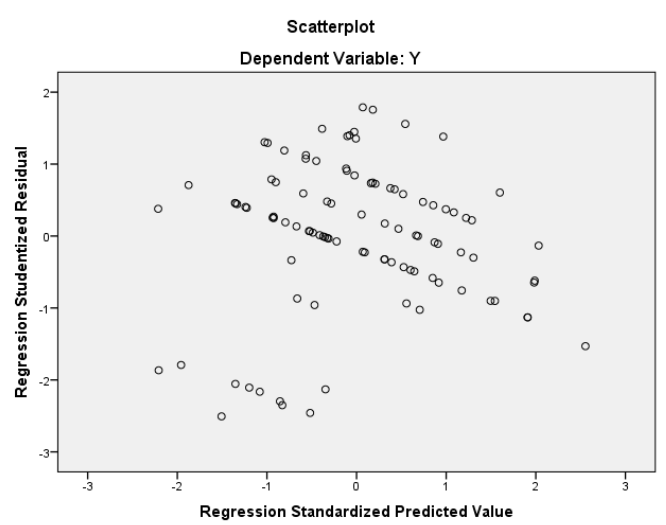

Hasil uji heteroskedastisitas menggunakan p plot SPSS diketahui tidak ada gejala heteroskedastisitas karena titik-titik menyebar diatas dan dibwah angka o sumbu Y yang tidak membentuk pola yang jelas. 


\section{e.Uji Linearitas}

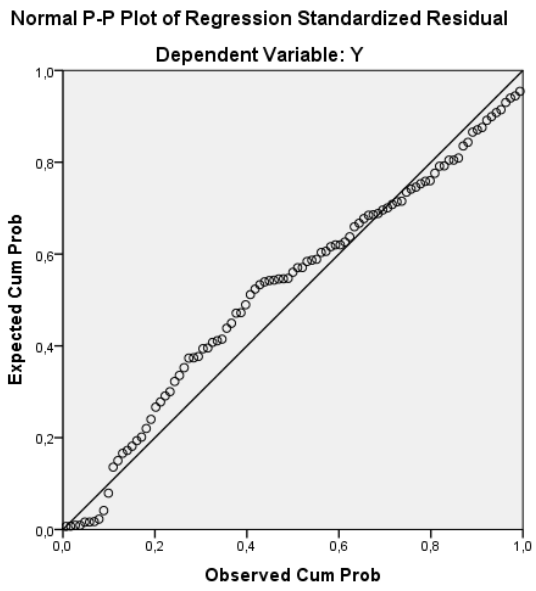

Hasil uji linearitas menggunakan p plot SPSS diketahui nilai residual berdistribusi normal karena titik-titik berada didekat atau mengikuti garis diagonalnya.

3. Uji Analisis

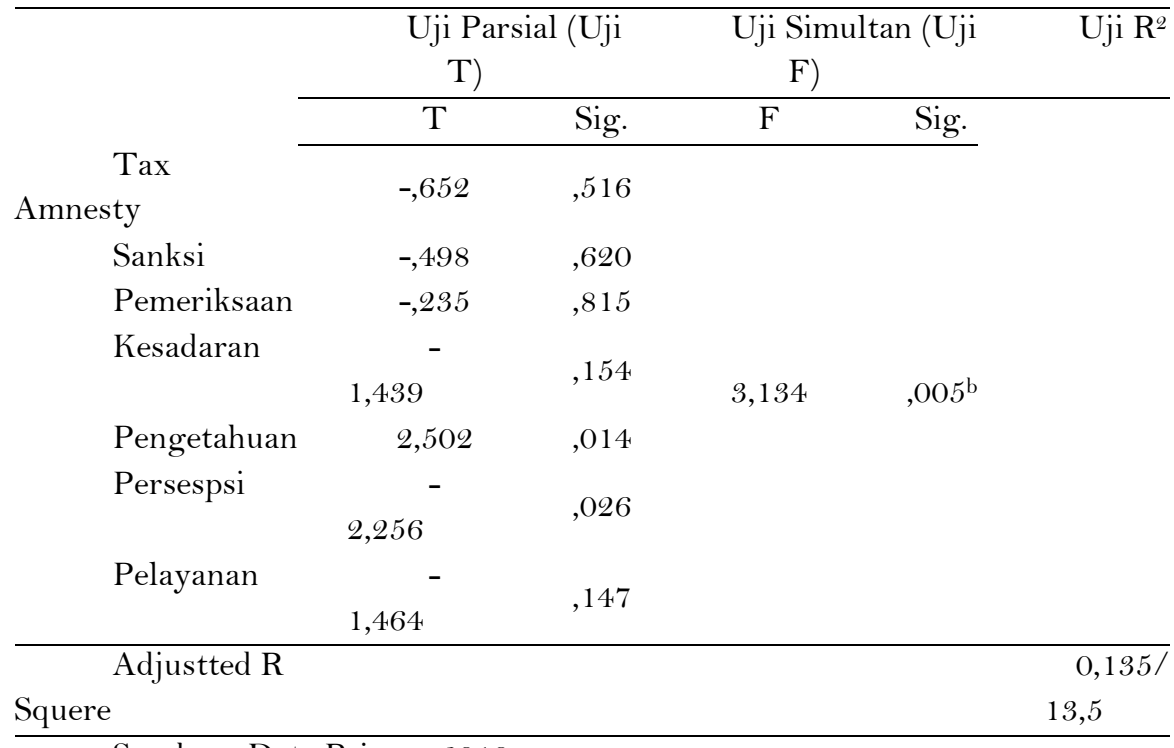

Sumber : Data Primer, 2019

Hasil uji analisis regresi berganda dengan uji $t$ pada masing-masing variabel, diperoleh nilai a pada variabel pengetahuan $(0,014)<0,05$ yang bermakna ada pengaruh pengetahuan terhadap kepatuhan pajak dan persepsi $(0,026)<0,05$ yang bermakna ada pengaruh persepsi terhadap kepatuhan pajak.

Sedangkan variabel tax amnesty $(0,516)>0,05$ yang bermakna tidak ada pengaruh tax amnesty terhadap kepatuhan pajak, sanksi $(0,620)>0,05$ yang bermakna tidak ada pengaruh sanksi terhadap kepatuhan pajak, pemeriksaan $(0,815)>0,05$ yang bermakna tidak ada pengaruh pemeriksaan terhadap kepatuhan pajak, kesadaran $(0,154)>0,05$ yang bermakna tidak ada pengaruh kesadaran terhadap kepatuhan pajak, dan pelayanan $(0,147)>0,05$ yang bermakna tidak ada pengaruh pelayanan terhadap kepatuhan pajak. 
Hasil uji $F$ diperoleh nilai $a(0,005)<0,05$ yang bermakna bahwa semua variabel independen (tax amnesty, sanksi, pemeriksaan, kesadaran, pengetahuan, persepsi, dan pelayanan) secara serentak dan signifikan mempengaruhi variabel dependen (kepatuhan pajak).

Hasil uji koefisien korelasi (R squere/ $\mathrm{R}^{2}$ ) diperoleh nilai koefisien korelasi 0,135/13,5\% yang bermakna bahwa variabel tax amnesty, sanksi, pemeriksaan, kesadaran, pengetahuan persepsi, dan pelayanan berpengaruh terhadap kepatuhan pajak sebesar $13,5 \%$.

\section{PEMBAHASAN}

\section{Pengaruh Tax Amnesty terhadap Kepatuhan Wajib Pajak}

Uji analisis regresi berganda dengan uji $t$ pada variabel tax amnesty $(0,516)>$ 0,05 yang bermakna tidak ada pengaruh tax amnesty terhadap kepatuhan pajak. Hasil peneltian ini berbeda dengan penelitian yang dilakukan Ngadiman dan Daniel Huslin (2015) menyatakan Tax amnesty berpengaruh positif dan signifikan terhadap kepatuhan wajib pajak. Penelitian lain yang dilakukan oleh Suhendro, dkk. (2018), tentang faktor-faktor yang mempengaruhi kepatuhan wajib pajak dalam membayar pajak, disimpulkan tax amnesty (X2) tidak ada pengaruh terhadap kepatuhan wajib pajak (Y) secara signifikan.

Tax amnesty adalah penghapusan pajak yang seharusnya terutang, tidak dikenai sanksi administrasi perpajakan dan sanksi pidana dibidang perpajakan, dengan cara mengungkap harta danmembayar uang tebusan (UU pengampunan pajak 2016). Tax amnesty bagian dari kebijakan negara sebagai upaya mendongkrak pendapatan Negara disektor pajak. Tax amnesty adalah kebijakan sewaktu yang hanya berlaku pada waktu terbatas. Banyak wajib pajak menyempatkan dan memanfaatkan peluang tax amnesty untuk melunasi tunggakan pajak. Namun disisi lain, tax amnesty tidak memberikan peluang kepada wajib pajak yang tidak dapat berkompetisi dengan waktu atau tidak ada kesesuaian antara peluang dan kemampuan. Hal tersebut berdampak pada kepatuhan wajib pajak dalam membayar pajak.

Variabel tax amnesty tidak berpengaruh pada kepatuhan wajib pajak di KPP Pratama Pamekasan karena tax amnesty adalah variabel yang terikat waktu dan telah lama dilakukan atau lewat masa waktunya. Pengukuran tax amnesty dalam penelitian ini bersifat retrospektif dengan ulasan yang mereview pengalaman responden dalam berpartisapasi atau tidak dalam tax amnesty. Pengukuran variabel tax amnesty juga bertujuan untuk meniliai efektifitas dan efisiensi tax amnesty dalam mengajak wajib pajak menunaikan kewajiban pajak yang terhutang. Dalam instrumen tax amnesty secara tersirat mendeskripsikan harapan responden tentang penyelenggaraan tax amnesty berikutnya yang menjangkau semua sasaran wajib pajak.

Mayoritas responden menginginkan adanya kebijakan dalam bentuk pengampunan pajak terhadap wajib pajak dengan memberi penghapusan pajak yang terhutang selama tahun pajak. Penghapusan pajak yang terhutang akan 
meningkatkan kemauan dan kemampuan responden untuk segera berpartisipasi dalam tax amnestysebagai upaya warga negara terbebas dari persoalan hukum. Responden juga menerpakan standart bahawa tax amnesty harus berdasarkan perhitungan uang tebusan dan pengungkapan harta wajib pajak. Kesesuaian nilai tunggakan dengan tebusan dapat meningkatkan kepercayaan wajib pajak dalam berpartisipasi dalam tax amnesty.

Responden masih belum meyakini bahwa tax amestydapat membebaskan pelanggar wajib pajak dari pemeriksaan pajak, penyidikan dan penagihan pajak. Keragu-raguan pada responden disinyalir karena pemahaman responden yang minim tentang tax amnesty. Namun disisi lain responden beranggapan bahwa tax amnesty memberikan manfaat bagi pelanggar wajib pajak dari sanksi administratif dan pidana. Proporsi jawaban responden tentang anggapan tax amnesty bukan sebagai jebakan cenderung berimbang ada yang beranggapan ragu-ragu adapula yang beranggapan murni sebagai pengampunan pajak.

\section{Pengaruh sanksi pajak terhadap kepatuhan wajib pajak}

Uji analisis regresi berganda dengan uji $t$ pada variabel sanksi $(0,620)>0,05$ yang bermakna tidak ada pengaruh sanksi terhadap kepatuhan pajak. Hasil peneltian ini berbeda dengan penelitian yang dilakukan Nurulita Rahayu (2017) menyatakan variabel ketegasan sanksi pajak berpengaruh positif terhadap kepatuhan wajib pajak. Penelitian lain yang dilakukan oleh Susmiatun dan Kusmuriyanto (2014) tentang pengaruh pengetahuan perpajakan, ketegasan sanksi perpajakan dan keadilan perpajakan terhadap kepatuhan wajib pajak UMKM di Kota Semarang menyatakan bahwa pada variabel ketegasan sanksi perpajakan secara parsial tidak berpengaruh terhadap kepatuhan Wajib Pajak

Sanksi perpajakan merupakan jaminan bahwa ketentuan peraturan perundang-undangan pajak (norma perpajakan) akan dituruti/ ditaati/ dipatuhi, atau dengan kata lain sanksi perpajakan merupakan suatu alat pencegah agar wajib pajak tidak melanggar norma perpajakan (Mardiasmo, 2006). Adanya sanksi seharusnya dapat memberikan rasa takut secara konstitusional terhadap pelanggar pajak. Sisi kontradiktif dari penerepan sanksi pajak adalah kemungkinan sanksi masih belum bisa diterapkan secara merata. Ada kecenderungan sanksi hanya menyasar kasus besar pelanggar pajak.

Sanksi pajak jelas diatur dalam norma hukum berupa produk perundangundangan yang bersifat mengikat dan memaksa. Responden mayoritas mengetahui bahwa sanksi bagi penunggak pajak berupa sanksi administratif dan pidana. Sanksi administratif dan pidana bagi penunggak pajak diharapkan dapat memberikan efek jera sehingga menjadi patuh dalam membayar pajak. Sanksi juga merupakan media pembelajaran atau sarana edukasi untuk mendidik wajib pajak agar selalu patuh membayar pajak.

Responden masih ada yang beranggapan bahwa sanksi pajak dapat ditoleransi karena opini penegakan hukum yang lemah dan tidak objektif. Bahkan sebagian besar responden beranggapan bahwa pengenaan sanksi atas pelanggaran 
pajak dapat dinegosiasikan. Fakta tersebut yang mempegaruhi konsistensi pengaruh sanksi pajak terhadap kepatuhan pajak sehingga variabel sanksi pajak tidak berpengaruh pada kepatuhan wajib pajak di KPP Pratama Pamekasan.

\section{Pengaruh pemeriksaan (audit probabilities) terhadap kepatuhan wajib pajak}

Uji analisis regresi berganda dengan uji $t$ pada variabel pemeriksaan $(0,815)$ $>0,05$ yang bermakna tidak ada pengaruh pemeriksaan terhadap kepatuhan pajak. Penelitian yang dilakukan Rizkilina P.A. dan Pratomo (2015) tentang pengaruh pengawasan dan konsultasi pajak dan pemeriksaan pajak terhadap tingkat kepatuhan pajak penghasilan badan Tahun 201 1-2013 pada KPP Madya Bandung, hasil penelitian ini menunjukkan bahwa kedua variabel (pengawasan dan konsultasi pajak dan pemeriksaan pajak) di KPP Madya Bandung tidak berpengaruh terhadap Tingkat Kepatuhan Pajak Penghasilan Badan.

Pemeriksaan adalah serangkaian kegiatan menghimpun dan mengolah data, keterangan, dan/atau bukti yang dilaksanakan secara objektif dan professional berdasarkan suatu standar pemeriksaan untuk menguji kepatuhan pemenuhan kewajiban perpajakan dan/atau untuk tujuan lain dalam rangka melaksanakan ketentuan peraturan perundang-undangan perpajakan. (pasal 1 angka $25 \mathrm{UU}$ KUP). Pemeriksaan merupakan prosedur yang wajib dilakukan petugas pajak kepada wajib pajak. Pemeriksaan yang dilakukan berdasar pada metode sistematis untuk mengetahui akurasi keterangan wajib pajak yang disampaikan kepada petugas. Pemeriksaan tidak berpengaruh pada kepatuhan pajak karena secara cultural orang pendompleng pajak biasanya berdalih sebagai alibi untuk mengelabui petugas.

Pemeriksaan merupakan tahapan prosedural yang harus dijalani wajib pajak ketika mengurus adminstrasi perpajakan. Responden cukup variatif dalam menjawab persoalan pemeriksaan Surat Pemberitahuan Tahunan (SPT) lebih bayar dan pengembalian pendahuluan pajak oleh petugas pajak. Persoalan tersebut terkait dengan sikap profesionalisme petugas pajak yang didasari penglaman masing-masing responden. Responden juga berpendapat berbeda bahwa pemeriksaan SPT yang tidak atau terlambat akan disampaikan kepada wajib pajak.

Hal terpenting dalam pemeriksaan pajak adalah penyampaian hasil pemeriksaan SPT yang mengindikasikan adanya kewajiban perpajakan wajib pajak yang tidak dipenuhi. Sebagian besar responden menjawab bahwa dengan pemeriksaan SPT negara tidak akan dirugikan oleh wajib pajak yang terindikasi belum atau kurang memenuhi kewajiban pajaknya. Jawaban responden yang variatif pada variabel pemeriksaan dengan dominasi jawaban ragu-ragu dan setuju mengakibatkan variabel pemeriksaan pajak tidak berpengaruh pada kepatuhan wajib pajak di KPP Pratama Pamekasan.

\section{Pengaruh Kesadaran terhadap Kepatuhan Wajib Pajak}

Uji analisis regresi berganda dengan uji $t$ pada variabel kesadaran $(0,154)>$ 0,05 yang bermakna tidak ada pengaruh kesadaran terhadap kepatuhan pajak. Hasil penelitian ini tidak sesuai dengan penelitian yang dilakukan Listyowati 
(2018) yang menyatakan kesadaran membayar pajak (X4) memengaruhi kepatuhan wajib pajak (Y) secara signifikan.

Penelitian lain yang dilakukan oleh Juwanti, F.R. (2017) tentang pengaruh pengetahuan perpajakan, kesadaran wajib pajak, norma sosial, kepercayaan pada pemerintah dan sanksi pajak terhadap kepatuhan wajib pajak dalam melakukan pembayaran pajak bumi dan bangunan, hasil penelitian menunjukkan bahwa variabel kesadaran wajib pajak tidak berpengaruh terhadap kepatuhan wajib pajak membayar Pajak Bumi dan Bangunan.

Kesadaran membayar pajak harus diikuti dengan sikap yang kritis. Pemerintah sebagai pengelola pajak dituntut untuk memberikan imbal balik yang dapat dirasakan secara nyata. Seperti fasilitas kesehatan gratis, prasarana transportasi, pendidikan, maupun sosial.

Kesadaran adalah hal positif yang ada dan menjadi karakteristik pada masing-masing responden. Mayoritas responden mempunyai kesadaran bahwa pajak adalah wajib dan memaksa bagai warga negara yang masuk kriteria wajib pajak sesuai perundang-undangan dan bentuk bentuk pengabdian masyarakat kepada negara. Responden yang patuh membayar pajak sebagai bentuk partisipasi responden dalam menunjang pembangunan negara.

Hal negatif terkait keadaran responden terhadap pajak dan pengaruhnya terhadap kepatuhan adalah hanya sebagian responden yang sadar bahwa penundaan pembayaran paja berdampak pada pengeurangan belanja negara sektor pajak. Selain itu, ada keraru-raguan pada jawaban responden bahwa pembayaran pajak yang tidak sesuai akan berdampak terhadap perncanaan belanja negara. Fakta tersebut sebagai domain yang mengakibatkan variabel kesadaran tidak berpengaruh terhadap kepatuhan wajib pajak di KPP Pratama Pamekasan.

\section{Pengaruh Pengetahuan tentang Pajak terhadap Kepatuhan Wajib Pajak}

Uji analisis regresi berganda dengan uji $t$ pada variabel pengetahuan $(0,014)$ $<$ 0,05 yang bermakna ada pengaruh pengetahuan terhadap kepatuhan pajak. Penelitian yang dilakukan Nanik Ermawati dan Zaenal Afifi (2018), tentang pengaruh pengetahuan perpajakan dan sanksi perpajakan terhadap kepatuhan wajib pajak dengan religiusitas sebagai variabel pemoderasi, hasil penelitian menunjukkan bahwa pengetahuan perpajakan berpengaruh terhadap kepatuhan wajib pajak.

Pengetahuan \& pemahaman tentang peraturan perpajakan merupakan proses dimana wajib pajak memahami tentang perpajakan kemudian menerapkan pengetahuan tersebut untuk membayar pajak. Resmi (2009) menyatakan bahwa solusi atas kasus tindak penggelapan atau penghindaran pajak adalah dengan melakukan sosialisasi Undang-Undang Perpajakan beserta sanksinya kepada para pelanggar ketentuan pajak tersebut. Hal ini didukung dengan adanya Keputusan Dirjen Pajak No.KEP-114/PJ./2005 tentang pembentukan tim sosialisasi perpajakan sebagai salah satu usaha pemerintah guna mencerdaskan masyarakat akan pengetahuan dan pemahaman peraturan perpajakan. 
Pengetahuan menjadi dasar perubahan dan pembentukan perilaku secara konsisten pada individu dan kelompok secara luas. Pengetahuan tentang pajak menjadi domain kemampuan wajib pajak mengetahui dan memahami tentang peraturan perpajakan secara utuh. Konsistensi pengetahuan wajib pajak akan meningkatkan pula kepatuhan dalam membayar pajak.

Responden berendapat bahwa pajak adalah kontribusi wajib kepada negara yang terhutang oleh orang pribadi atau badan yang bersifat memaksa berdasarkan undang-undang, dengan tidak mendapatkan imbalan secara langsung. Sebagian besar responden mengetahui bahwa ada kewajiban yang melekat bagi setiap warga Negara untuk membayar pajak. Kewajiban membayar pajak melahirkan sebuah konsekuensi hukum apabila tidak ditunaikan.

Responden juga mengetahui bahwa pajak berfungsi untuk menghimpun dana dari masyarakat yang diperuntukkan untuk pembiayaan negara dan sebagai alat untuk mengatur struktur pendapatan masyarakat dan struktur kekayaan antara para pelaku ekonomi. Partisipasi responden dalam membayar pajak sebagai bukti kontribusi warga negara terhadap pembangunan dan pertumbuhan ekonomi negara. Selain itu, sebagian besar responden juga mengetahui bahwa penghitungan jumlah pajak didasarkan atas penghasilan dan atau harta kekayaan yang wajib dikeluarkan pajaknya. Ada rumusan dalam menentukan besaran jumlah pajak sehingga tidak terjadi ketimpangan antara penghasilan dan besaran nilai pajak pada wajib pajak.

\section{Pengaruh Persepsi atas Efektivitas Sistem Perpajakan terhadap Kepatuhan wajib pajak}

$\mathrm{Uji}$ analisis regresi berganda dengan uji $t$ pada variabel dan persepsi $(0,026)$ $<$ 0,05 yang bermakna ada pengaruh persepsi terhadap kepatuhan pajak. Penelitian yang dilakukan Sutiyono (2013), menyatakan bahwa variabel persepsi atas efektivitas sistem perpajakan memberikan pengaruh positif terhadap kepatuhan formal Wajib Pajak Orang Pribadi dan jika terjadi peningkatan variabel persepsi atas efektivitas sistem perpajakan sebesar satu satuan maka dapat meningkatkan kepatuhan formal Wajib Pajak Orang Pribadi dengan asumsi variabel bebas lainnya konstan/tidak berubah.

Persepsi dapat dinyatakan sebagai suatu proses pengorganisasian, pengintepretasian terhadap stimulus oleh organisasi atau individu sehingga merupakan suatu yang berarti dan merupakan aktivitas integrated dalam diri individu. Sedangkan efektivitas memiliki pengertian suatu pengukuran yang menyatakan seberapa jauh target (kualitas, kuantitas dan, waktu) telah tercapai (Widayati dan Nurlis, 2010). Persepsi wajib pajak terhadap perpajakan di KPP Pratama Pamekasan pasti berbeda satu dengan yang lainnya. Perbedaan persepsi wajib pajak selaras dengan arah perkembangan kehidupannya. Interpretasi dari stimulus sistem perpajakan yang masih belum sempurna membentuk persepsi yang mempengaruhi kepatuhan wajib pajak membayar pajak.

Persepsi responden atas efektivitas sistem perpajakan merupakan uraian dari penerapan dan pemanfaatan sistem perpajakan yang ada di KPP Pratama 
Pamekasan. Sistem perpajakan di KPP Pratama Pamekasan telah mengalami masa transisi parsial dari manual menuju era digital. Pembayaran, pelaporan, penyampaian SPT pajak dapat dilakukan secara online dan offline serta terdapat media informasi menggunakan media digital. Persepsi responden atas sistem pelayanan perpajakan berbeda-beda dengan proporsi yang hampir sama antara yang positif dan negatif. Sebagian responden mempersepsikan bahwa pembayaran pajak secara online (e-banking) adalah mudah, aman, dan terpercaya sedangkan sebagian lainnya beranggapan ragu-ragu atas kemudahan dan keamanannya.

Persepsi responden tentang pelaporan pajak melalui e-SPT dan e-filling serta penyampaian SPT melalui drop box juga dengan persepsi bervariasi. Sebagian respoden yang mempersepsikan efektif dan mudah ada juga yang mempersepsikan ragu-ragu atau bahkan kurang efektif dan sulit. Perbedaan persepsi atas sistem perpajakan di KPP akan menentukan kepatuhan wajib pajak dalam membayar pajak.

\section{Pengaruh Pelayanan Pajak terhadap Kepatuhan Wajib Pajak}

Uji analisis regresi berganda dengan uji $t$ pada variabel pelayanan pajak $(0,147)>0,05$ yang bermakna tidak ada pengaruh pelayanan pajak terhadap kepatuhan pajak. Penelitian lain yang dilakukan oleh Ulynnuha, O.I. (2018) tentang analisis faktor-faktor yang mempengaruhi kepatuhan wajib pajak dalam memenuhi kewajibannya, hasil penelitian menunjukkan bahwa variabel kualitas pelayanan fiskus dan sanksi perpajakan tidak berpengaruh terhadap kepatuhan wajib pajak.

Pelayanan pajak merupakan pelayanan jasa untuk menjawab semua tuntutan dari pengguna jasa (wajib pajak). Persoalan pajak bukan lagi persoalan kecakapan pelayanan melainkan persoalan finansial dan partisipasi warga negara terhadap perkembangan negara.

Pelayanan perpajakan adalah upaya dasar KPP Pratama Pamekasan untuk menarik perhatian wajib pajak dalam membayar pajak. Jawaban responden tentang pelayan pajak di KPP Pratama Pamekasan mayoritas adalah positif. Sebagian besar respoden menilai bahwa petugas di KPP Pratama Pamekasan telah memberikan pelayanan pajak dengan baik. Respon den sebagaian besar menilai bahwa penetapan pajak yang kurang bayar telah dilakukan sesuai dengan ketentuan perpajakan yang berlaku.

Dari sisi penyampain informasi, petugas pajak talah dianggap memberikan informasi dan penjelasan dengan jelas dan mudah dimengerti kepada wajib pajak. Petugas pajak juga telah mengarahkan tanpa mempengaruhi responden dalam mengurus administrasi perpajakan. Proporsi jawaban responden tentang prosedur pembayaran pajak di KPP Pratama pamekasan masih bersifat variatif, sebagian responden menjawab mudah dan sebagian lainnya menjawab ragu-ragu. 
Pengaruh tax amnesty, sanksi pajak, pemeriksaan, kesadaran, pengetahuan, persespi, dan pelayanan pajak terhadap kepatuhan pajak

Hasil uji $F$ diperoleh nilai a $(0,005)$ yang bermakna bahwa semua variabel independen (tax amnesty, sanksi, pemeriksaan, kesadaran, pengetahuan, persepsi, dan pelayanan) secara serentak dan signifikan mempengaruhi variabel dependen (kepatuhan pajak).

Hasil uji Koefisien determinasi ( $\mathrm{R}$ square $/ \mathrm{R}^{2}$ ) diperoleh nilai koefisien korelasi 0,135/13,5\% yang bermakna bahwa variabel tax amnesty, sanksi, pemeriksaan, kesadaran, pengetahuan, persepsi, dan pelayanan berpengaruh terhadap kepatuhan pajak sebesar $13,5 \%$.

Kepatuhan membayar pajak pada responden dinilai dari kebenaran, kelengkapan, dan kejelasan pengisian formulir SPT. Kuailitas pengisian SPT berhubungan dengan perhitungan dengan benar untuk besaran nilai pajak yang menjadi kewajiban responden. Kepatuhan responden juga harus diukur dari sejauh mana responden tapat waktu melakukan pelaporan dan pembayaran pajak. Faktor yang menentukan kepatuhan wajib pajak membayar pajak hanya dapat ditentukan secara relatif tanpa ada standar mutlak. Beberapa faktor secara bersama akan mempengaruhi kepatuhan wajib pajak dalam membayar pajak. Faktor kolektif ditunjang dari beberapa faktor dalam satu kajian yang biasanya tidak bernilai sama dalam situasi berbeda.

\section{KESIMPULAN}

Hasil analisis regresi berganda dengan uji $t$ pada variabel pengetahuan diperoleh nilai $p$ value $(0,014)<0,05$ dan pada variabel persepsi $(0,026)<0,05$ yang bermakna ada pengaruh pengetahuan dan persepsi terhadap kepatuhan pajak di KPP Pratama Pamekasan.

Hasil analisis regresi berganda dengan uji $t$ pada variabel tax amnesty diperoleh nilai $p$ value $(0,516)>0,05$, variabel sanksi $(0,620)>0,05$, variabel pemeriksaan $(0,815)>0,05$, variabel kesadaran $(0,154)>0,05$, dan variabel pelayanan pajak $(0,147)>0,05$ yang bermakna tax amnesty, sanksi, pemeriksaan, kesadaran, dan pelayanan tidak berpengaruh terhadap kepatuhan pajak di KPP Pratama Pamekasan.

Hasil analisis regresi berganda dengan uji $F$ diperoleh nilai $a(0,005)<0,05$ yang bermakna bahwa semua variabel independen (tax amnesty, sanksi, pemeriksaan, kesadaran, pengetahuan, persepsi, dan pelayanan) secara serentak dan signifikan mempengaruhi variabel dependen (kepatuhan pajak) di KPP Pratama Pamekasan.

\section{DAFTAR PUSTAKA}

Mardiasmo. (2008). Perpajakan Edisi Revisi. Yogyakarta : Andi Offset.

Resmi, Siti. (2011). Perpajakan: Teori dan Kasus Edisi 6. Jakarta : Penerbit Salemba Empat. 
Denziana, dan Sutanto, H. (2015). Pengaruh Peran Acoount Representative terhadap Tingkat Kepatuhan Wajib Pajak (Studi Kasus pada KPP Pratama di Kota Bandar Lampung). JURNAL Akuntansi \& Keuangan Vol. 6, No. 1, Maret 2015 Halaman 1-22

James, S., dan Alley, C. (2004). Tax Compliance, Self-Assessment and Tax Administration. Journal of Finance and Management in Public Services, Vol. 2. No. 2. Pp. 27-42.

Juwanti, F.R. (2017). Pengaruh Pengetahuan Perpajakan, Kesadaran Wajib Pajak, Norma Sosial, Kepercayaan pada Pemerintah dan Sanksi Pajak terhadap Kepatuhan Wajib Pajak dalam Melakukan Pembayaran Pajak Bumi dan Bangunan (Studi pada Wajib Pajak Bumi dan Bangunan Kecamatan Colomadu Kabupaten Karanganyar). Jurusan Akuntansi Syariah Fakultas Ekonomi dan Bisnis Islam Institut Agama Islam Negeri Surakarta.

Listyowati, dkk. (2018). Faktor-Faktor yang Mempengaruhi Kepatuhan Wajib Pajak dalam Membayar Pajak. Jurnal Riset Akuntansi dan Bisnis Airlangga vol. 3. no. 1 (2018) 372-395 ISSN 2548-4346 (online)

Oladipupo, A. O., dan Obazee, U. (2016). Tax Knowledge, Penalties and Tax Compliance in Small and Medium Scale Enterprises in Nigeria. Business, Vol. 2. No. 1. Pp. 1-9.

Rizkilina P.A. dan Pratomo. (2015). Pengaruh Pengawasan dan Konsultasi Pajak dan Pemeriksaan Pajak terhadap Tingkat Kepatuhan Pajak Penghasilan Badan Tahun 2011-2013 pada KPP Madya Bandung. ISSN : 2355-9357 eProceeding of Management : Vol.2, No.2 Agustus 2015.

Suhendro, dkk. (2018). Faktor-Faktor yang Mempengaruhi Kepatuhan Wajib Pajak dalam Membayar Pajak. Jurnal Riset Akuntansi dan Bisnis Airlangga Vol. 3. No. 1 (2018) 372-395 ISSN 2548-1401 (Print) ISSN 2548-4346 (Online).

Suyono dan Nanang, A. (2016). Faktor-Faktor yang Mempengaruhi Kepatuhan

Membayar Pajak di Kantor Pelayanan Pajak Wonosobo. Jurnal ppkm i (2016) 1-10

Sutiyono, Agus E. (2013). Analisis Faktor-faktor yang Mempengaruhi Kepatuhan Formal Wajib Pajak Orang Pribadi (Studi Kasus pada KPP Pratama Blitar).

Skripsi Fakultas Ekonomi Dan Bisnis Universitas Airlangga.

Ulynnuha, O.I. (2018). Analisis Faktor-faktor yang Mempengaruhi Kepatuhan Wajib Pajak dalam Memenuhi Kewajibannya. Program Studi Akuntansi Fakultas Ekonomi Dan Bisnis Universitas Muhammadiyah Surakarta. 